\title{
PERSPEKTIF AL-QUR'AN TENTANG KONTEN TARIAN VIRAL PARA MUSLIMAH PADA APLIKASI TIK TOK
}

\section{THE QURAN PERSPECTIVE ON CONTENT VIRAL DANCES OF MUSLIMAH ON THE APPLICATION TIK TOK}

\author{
Sania Alfaini \\ Institut Agama Islam Negeri Surakarta \\ Shania.alfaini86@gmail.com
}

\begin{abstract}
Abstrak
Artikel ini membahas tentang perspektif Al-Qur'an terhadap konten tarian viral para muslimah di aplikasi Tik Tok. Disimpulkan bahwa banyak faktor penyebab para msulimah melakukan tarian tersebut yakni eksistensialisme yang ingin ditonjolkan oleh para muslimah, faktor gaya hidup yang membuat muslimah mudah mengikuti hal yang sedang viral, faktor lemahnya pengetahuan agama, dlln. Sedangkan dampak yang diterima para Muslimah yakni aurat mereka menjadi terbuka, mudah dilihat oleh lelaki non-mahram , memicu muslimah lain untuk mengikutinya dan dapat menyebabkan fitnah bagi muslimah itu sendiriDiperspektifkan kepada Al-Qur'an diantaranya Surat An-Nur ayat 31, Surat AlAhzab ayat 33 dan Surat Al-Ahzab ayat 59.

Kata Kunci : Tik Tok; Tarian Muslimah; Perspektif Al-Qur'an

Abstract

This article discusses the perspective of the Qur'an on the viral dance content of Muslim women on the Tik Tok application. It was concluded that many factors caused Muslim women to perform the dance, namely existentialism that Muslim women want to highlight, lifestyle factors that make it easy for Muslim women to follow things that are viral, weak religious knowledge, etc. While the impact received by Muslim women is that their genitals become open, easily seen by non-mahram men, triggering other Muslim women to follow them and can cause slander for Muslim women themselves. From the perspective of the Qur'an, including Surah An-Nur verse 31, Surah Al- Ahzab verse 33 and Surah Al-Ahzab verse 59.
\end{abstract}

Keywords: Tik Tok; Muslim dance; The perspective of the Qur'an

\section{PENDAHULUAN}

Seiring dengan kemajuan teknologi, banyak para generasi muda yang memanfaatkan segala kebutuhannya melalui Internet. Dilansir pada laman kominfo.go.id, menurut hasil survei Kominfo, pengguna Internet di Indonesia pada tahun 2020 mencapai 196,7 Juta ${ }^{1}$. Dari jumlah tersebut menunjukkan pengguna internet di Indonesia mencapai 73,7\% dari seluruh penduduk Indonesia. Dengan kata lain, hampir seluruh kegiatan masyarakat Indonesia bergantung pada Internet, salah satunya dalam memenuhi kebutuhan. Kebutuhan itu mulai dari yang sifatnya primer seperti pendidikan, ekonomi, kesehatan agama, sosial maupun budaya hingga kebutuhan yang bersifat sekunder salah satunya hiburan. Hiburan dengan mudahnya

${ }^{1}$ Www.Kominfo.go.id Dilansir oleh Ditjen PPI pada 09 November 2020 dan diakses Pada 02 
didapatkan dari Internet, baik berbentuk aplikasi, video, foto maupun website yang saat ini dengan mudah diakses oleh semua orang. Saat ini, aplikasi handphone yang paling banyak digunakan oleh para pengguna internet. Aplikasi yang paling banyak diminati adalah platform sosial media, shopping, game dan video musik. Salah satu aplikasi yang banyak digandrungi anak muda saat ini adalah tik-tok, instagram, youtube, whatsapp, telegram, dlln.

Pada pembahasan ini, subyek yang akan diangkat adalah penggunaan aplikasi tik-tok yang marak di kalangan remaja hingga dewasa. Tiktok merupakan aplikasi video-musik yang dibuat oleh negara Cina dan saat ini marak digunakan kalangan orang Indonesia ${ }^{2}$. Banyak hal yang saat ini menjadi standar "viral" para remaja hanya karena postingan video-musik dari tiktok. Semua informasi yang tertuang dalam bentuk video-musik pada aplikasi tiktok dapat diambil dengan mudahnya, entah itu berbentuk perbuatan, perkataan maupun suatu ketetapan. Seperti tarian pada video tik-tok yang saat ini menjadi syndrome bagi para pendengarnya, tak terkecuali para muslimah yang menjadi korban viralnya aplikasi tik-tok. Banyak dari muslimah dengan rasa percaya dirinya mengunggah video-musik yang memamerkan lenggaklenggok tubuhnya di tik-tok. Hal tersebut seharusnya diketahui oleh para muslimah tentang batasan aurat yang boleh ditunjukkan kepada lawan jenis, utamanya pada platform tik-tok dimana semua orang bisa mengakses video-musik dengan mudahnya. Terkadang dibalik unggahan video-musik tersebut ada beberapa orang yang memanfaatkannya untuk kepentingan yang berbau ponografi.

Karena banyaknya konten yang tidak sepantasnya ditonton oleh seluruh kalangan Abdulhakim melakukan penelitian tentang komunikasi orangtua terhadap tayangan anak pada aplikasi tik-tok yang semestinya harus diawasi ${ }^{3}$, hal tersebut menunjukkan bahwa video-musik yang disajikan sebagian mengandung konten yang negatif bagi kalangan anak-anak, di sisi lain Cahyani juga mengungkapkan bahwa tik-tok memudahkan anak untuk mencari informasi terbaru maupun teraktual ${ }^{4}$. Walaupun tidak semua konten video-musik didalamnya mengandung unsur negatif, yakni dapat digunakan untuk menyebarkan dakwah dengan algoritma penyampaian sesuai dengan kejadian yang dialami oleh anak muda saat ini ${ }^{5}$.

Sebagai umat muslim, sudah seharusnya kita berpedoman pada Al-Qur'an dan Hadits, terutama dalam menghadapi fitnah di akhir zaman ini. Al-Qur'an diturunkan untuk menjadi pedoman bagi manusia, selayaknya kita sebagai orang yang beriman memahaminya dari berbagai perspektif terutama kaitannya dengan fenomena kontemporer saat ini.Fenomena tarian wanita pada aplikasi tik-tok tersebut menjadi obyek yang harus dikaitkan dengan perspektif pedoman kita, yakni Al-

\footnotetext{
${ }^{2}$ Rahmawati, S. Fenomena Pengguna Aplikasi Tik Tok Dikalangan Mahasiswa Universitas Pasundan Bandung (Doctoral Dissertation: PERPUSTAKAAN,2018).

3 Arrofi,Abdulhakim. Memahami Pengalaman Komunikasi Orangtua-Anak Ketika Menyaksikan Tayangan Anak-anak di Media Sosial Tik Tok .Jurnal Interaksi Online 7(3).2019:203208.

${ }^{4}$ Cahyani, Dini Dwi. Dampak Penggunaan Aplikasi Tik Tok dalam Interaksi Sosial (Study Kasus di SMA Negeri 11 Teluk Belitung Timur Bandar Lampung). (Doctoral Dissertasion : UIN Raden Intan Lampung, 2021)

5 Amelia.R, dkk. Pesan Dakwah Husain Basyaiban dalam Konten Tik Tok.(Doctoral Dissertasion: UIN Sulthan Thaha Saifuddin Jambi,2021).
} 
Qur'an. Perihal bagaimana seorang muslim menyikapi hal tersebut dan hukum yang harus ditegakkan terhadap fenomena yang sudah terjadi.

Beberapa Rumusan Masalah yang dapat diambil diantaranya Pertama,Apa faktor utama yang menyebabkan muslimah mengikuti tarian viral di aplikasi tik-tok? Kedua, Apa dampak yang disebabkan muslimah mengikuti tarian viral di aplikasi tik-tok? Ketiga, Bagaimana perspektif Al-qur'an dalam menanggapi fenomena tersebut?. Dari beberapa rumusan masalah tersebut, maka tujuan penelitian ini adalah Untuk mengetahui faktor utama para muslimah jika mengikuti tarian viral di aplikasi tik-tok, mengetahui dampak yang disebabkan muslimah mengikuti tarian viral di aplikasi tik-tok dan untuk mengetahui sisi prespektif Al-Qur'an dalam menanggapi fenomena tersebut.

\section{PEMBAHASAN}

\section{Faktor Utama para muslimah mengikuti tarian viral di aplikasi tik-tok}

Ada beberapa alasan yang mendasari seseorang mengikuti tarian viral di tiktok. Pertama, ditinjau dari konsep dasarnya, manusia memiliki keadaan eksistensialisme yakni suatu sikap manusia dimana ingin menunjukkan dirinya agar lingkungannya terpengaruh dengannya, hal tersebut dikemukakan oleh ahli eksistensialisme, Sartre ${ }^{6}$. Eksistensi yang ditunjukkan kepada khalayak umum berupa sesuatu hal yang bisa dibanggakan dari dirinya, entah itu prestasi maupun fisik. Namun, sayangnya yang banyak kita jumpai di aplikasi tik-tok adalah viralnya tari-tarian tersebut.

Kedua, adanya gaya hidup manusia yang dipengaruhi oleh sekitarnya, sebagaimana pendapat Damsar bahwa suatu gaya hidup terbentuk dari pengaruh ikatan suatu kelompok yang saling berkompetisi ${ }^{7}$, maka kebiasaan pola hidup seseorang tidak lepas dari pengaruh orang disekitarnya sebagaimana mudahnya muslimah menarikan tarian viral tersebut, dikarenakan banyak yang menjadikannya sebagai " tolak ukur" atau tren yang sedang asik-asiknya dijadikan suatu bahan untuk dipertontonkan.

Ketiga, dikarenakan faktor lemahnya pengetahuan keislaman muslimah tentang batasan dalam menampakkan aurat, sebagaimana disebutkan perintah dan larangannya dalam Al-Quran.Menurut Alport, seseorang yang memiliki kematangan dalam beragama akan memiliki sikap yang mampu mengharmoniskan rasio dengan dogma, mengobservasi dan mengkritik tanpa meninggalkan ketaatannya ${ }^{8}$. Hal ini menunjukkan bahwa muslimah seharusnya memiliki kematangan dalam berpikir dan memahami ilmu agama secara mendalam agar dapat membedakan mana hal yang bersifat syubhat dan mana hal yang membawa kepada kemanfaatan. Selain itu Alport

\footnotetext{
${ }^{6}$ Tambunan, S. F. Kebebasan Individu Manusia Abad Dua Puluh: Filsafat Eksistensialisme Sartre. Jurnal Masyarakat Dan Budaya, 18(2), 59-76, (2016).

7 Tana, S. O., \& Bessie, J. L. Pengaruh Gaya Hidup Dan Kualitas Layanan Terhadap Keputusan Pembelian (Studi Pada Pelanggan X2 Family Resto And Karaoke Kupang). Journal Of Management: Small And Medium Enterprises (Smes), 13(3), 255-270,(2020).

${ }^{8}$ Indirawati, E. Hubungan Antara Kematangan Beragama Dengan Kecenderungan Strategi Coping. Jurnal Psikologi, 3(2), 69-92, (2006).
} 
juga berpendapat bahwa seseorang yang berpikir mendalam tentang agama kaan menjadikan agama sebagai pedoman hidup dalam kesehariannya, agamalah yang akan mendinamiskan segala prinsip yang ada dalam kehidupannya. Apabila seorang muslimah bisa menempatkan agama sebagai hal utama dalam kehidupannya, maka muslimah tidak akan mudah terdinamiskan dengan hal-hal yang sedang ramai diperbincangkan atau dipertontonkan seperti tarian viral yang ada di aplikasi videomusik tiktok tersebut.

Keempat, Pemenuhan kebutuhan hiburan yang dilakukan oleh para pengguna internet, utamanya muslimah.Sebagaimana diungkapkan oleh Horrigan (2002) bahwa salah satu dari empat kategori pengguna internet kebanyakan adalah untuk memenuhi kebutuhan hiburan entah untuk bermain game, melihat videomusik, chatting, mendengarkan musik, dlln ${ }^{9}$. Hal ini menunjukkan bahwa muslimah yang mengunggah video-musik tarian yang sedang viral di aplikasi tik-tok merupakan bagian dari memenuhi kebutuhan hiburan. Terlebih, apabila muslimah tersebut kurang efisien dalam menggunakan waktu luangnya.Sebagaimana suatu pepatah baahsa arab mengatakan "tidak akan kembali hari-hari yang telah berlalu", alangkah baiknya jika waktu luang yang tersedia dimanfaatkan untuk hal-hal yang bermanfaat.

Kelima, faktor ekonomi yang menjadikan tarian di aplikasi tik-tok bisa menghasilkan uang.Menurut hasil penelitian Ipan Ripai tiktok merupakan aplikasi video-musik yang menyediakan banyak iklan didalamnya, sehingga dapat menghasilkan pundi-pundi uang bagi pemakainya ${ }^{10}$. Ada kaitan antara tarian viral tersebut terhadap iklan tik-tok ini,yakni untuk menambah personal branding para pengunggah video-musik di laman tik-tok untuk menambah popularitasnya atau nantinya untuk memasarkan produk mereka. Apabila dikaitkan dengan muslimah yang mengunggah video tarian tersebut, alangkah lebih baiknya pemasaran produk dilakukan dengan cara-cara unik seperti konten berbentuk animasi ataupun konten yang sifatnya tidak menunjukkan kemolekan tubuh seorang muslimah.

\section{Dampak Muslimah Mengikuti Tarian Viral di Aplikasi Tik-Tok}

Seiring kemajuan teknologi, mudahnya beredar segala informasi, termasuk hal-hal yang sifatnya menghibur seperti konten-konten yang berbentuk musik, video maupun video-musik bagi para pengguna internet. Banyak kita temui konten hiburan tersebut kebanyakan adalah hal-hal yang sedang hangat-hangatnya dibicarakan oleh masyarakat, sayangnya konten yang mudah diterima di kalngan masyarakat adalah konten yang dirasa kurang bermanfaat. Salah satunya tarian viral di tik-tok, dimana semua orang bisa dengan mudah mempraktikkannya. Para muslimahlah yang menjadi salah satu bagian yang menjadi target dari viralnya aplikasi tik-tok tersebut. Diantara dampak yang disebabkan apabila seorang Muslimah mengikuti tarian viral di tik-tok adalah sebagai berikut:

a. Tarian viral di aplikasi tik-tok menyebabkan terlihatnya aurat muslimah, terutama lekuk tubuhnya. Banyak dari para muslimah melakukan tarian

\footnotetext{
${ }^{9}$ Novianto, I.. Perilaku Penggunaan Internet Di Kalangan Mahasiswa. Surabaya: Universitas Airlangga. (2011)

${ }^{10}$ Prodi, P. T. I. K. Analisis Pertandingan Antara Facebook Ads Dengan Tiktok Ads Terbadap Perkembangan Bisnis Penjualan Online Di Era Digital. ICT Learning, 7(2).(2020).
} 
viral pada aplikasi tik-tok dengan gerakan yang kurang sopan. Sehingga lekukan tubuh mereka terlihat, dimana hal itu bertolak belakang dengan fungsi pakaian seorang muslimah yakni untuk menutupi aurat.

b. Berkurangnya kemuliaan / muru'ah seorang muslimah

Tarian ataupun goyangan yang ditampilkan para muslimah pada aplikasi tiktok memberikan tanda bahwa muslimah memiliki sedikit rasa malu. Padahal kemuliaan seorang wanita terletak pada tingginya rasa malu yang dimiliki.

c. Banyaknya mata lelaki yang bukan mahram melihat video-musik tarian muslimah di aplikasi tik-tok, dikarenakan sudah tak ada lagi batasan dalam pengunggahan video-musik pada aplikasi tik-tok membuat hal tersebut menjadi mudah untuk dikonsumsi oleh semua orang, tak terkecuali para lelaki yang bukan mahram para muslimah tersebut.

d. Memicu muslimah lain untuk mengikuti tarian viral tersebut. Tingginya pengaruh suatu hal yang sedang naik daun, menyebabkan beberapa orang disekitarnya ikut melakukan hal tersebut.Menurut Diktat Filsafat manusia menyebutkan bahwa manusia selalu memiliki berpendirian dalam menentukan sikapnya ${ }^{11}$, dalam hal ini seharusnya para muslimah tidak mudah ikut dalam penyebaran konten-konten hiburan yang sedang viral, terlebih konten tersebut tidak membawa kepada hal yang bermanfaat tetapi menimbulkan madharat yang lebih besar.

e. Memicu kepada tindakan yang menyebabkan fitnah.

Beberapa hal buruk yang dianalisis dapat terjadi adalah tampilan videomusik tarian para muslimah di aplikasi tik-tok dapat disalahgunakan, terlebih untuk hal yang berkaitan dengan pornografi. Sebagaimana yang sudah dilansir pada laman web medan.tribunnews.com pada 22 oktober 2020 oleh Taridan turnip bahwa ada ratusan ribu foto perempuan diedit oleh oknum tak bertanggungjawab menjadi foto tanpa berpakaian ${ }^{12}$.

Tidak bisa dipungkiri, bahwa tarian para muslimah yang sedang viral di aplikasi video-musik tik-tok dapat diedit menjadi video tanpa busana oleh oknum yang serupa, sehingga bisa menyebabkan penyalahgunaan fungsi media sosial dan pencemaran nama baik bagi korban yang terlibat.Hal tersebut menunjukkan bahwa tarian viral tidak membawa keuntungan bagi muslimah, akan tetapi kerugianlah yang paling banyak diterima oleh mereka. Berdasarkan penelitian yang dilakukan oleh Trie Damayanti dan Ilham Gemiharto bahwa mayoritas pengguna tik-tok didominasi oleh perempuan, tak jarang dari mereka yang menggunakan pakaian terbuka dan menunjukkan beberapa bagian tubuhnya, setelah mewawancarai beberapa responden pria banyak dari mereka yang pernah menyaksikan konten wanita dengan pakaian maupun tarian yang sangat menonjolkan bagian tubuh mereka ${ }^{13}$. Jika disetarakan

11 Afanda, A. A. Kasus Penyebaran Hoaks Di Indonesia Dalam Sudut Pandang Filsafat Manusia.Universitas Widya Mandala:Madiun. (2019).

${ }^{12}$ Www.Medan.Tribunnews.Com Dilansir Oleh Taridan Turnip Pada 22 Oktober 2020 Dan Diakses Pada 3 Maret 2021.

${ }^{13}$ Damayanti, T., \& Gemiharto, I. Kajian Dampak Negatif Aplikasi Berbagi Video Bagi AnakAnak Di Bawah Umur Di Indonesia. Communication, 10(1), 1-15. (2019). 
dengan muslimah, maka konten video-musik pada aplikasi tik-tok juga bisa menyebabkan pandangan para pria itu untuk melihat kemolekan tubuh mereka, terlebih ditambah dengan tarian-tarian yang sedang viral di aplikasi tik-tok tersebut.

\section{Perspektif Al-Qur'an dalam menanggapi fenomena video tarian muslimah di aplikasi tik-tok}

Melihat banyaknya hiburan di jejaring sosial media yang mudah tersebar, menyebabkan para penggunanya harus berhati-hati dalam memilah dan memilih untuk dikonsumsi. Karena tidak semua yang ada di internet bisa dengan mudahnya diterima oleh para pengguna. Seperti halnya pada unggahan video tarian viral para muslimah pada aplikasi tik-tok. Hal tersebut menjadi konsumsi siapa saja tanpa terkecuali para pengguna pada aplikasi tik-tok. Dari sini peran penting orangtua dan kekuatan iman sangat dibutuhkan bagi seorang muslim/muslimah dalam menjelajahi dunia internet. Hal terpenting yang bisa dijadikan pedoman kembalinya segala urusan seorang muslim/muslimah adalah dua sunnah yang harus dipegang teguh, yakni Al-Qur'an dan Hadits. Poin pembahasan pada karya ini adalah perspektif AlQur'an menanggapi fenomena video tarian viral muslimah pada aplikasi tik-tok. Berikut penjelasan Al-Qur'an terhadap fenomena tersebut : Al-Qur'an melarang wanita menampakkan aurat dihadapan laki-laki yang bukan mahramnya.

Secara bahasa, dalam kamus Al-Munawwir Aurat berasal dari mashdar (bentukan kata) bahasa arab yakni al-'aurat yang berarti semua perkara yang sifatnya malu $^{14}$. Dapat difahami bahwa aurat berkaitan dengan hal-hal yang seharusnya tidak ditampakkan kepada orang lain untuk menutupi rasa malu.

Dalam hal ini, islam mengatur segala hukum dari hal-hal yang bersifat remeh hingga penting. Sebagaimana islam juga menghormati kemuliaan wanita, dengan menetapkan batasan pada tiap-tiap yang berkaitan dengannya, salah satunya adalah aurat wanita. Dalam Q.S An-Nur: 31 disebutkan bahwa "Dan janganlah mereka menampakkan perhiasan mereka kecuali yang (biasa) nampak pada mereka" menurut tafsir Ibnu Katsir ayat ini ditafsirkan bagi para perempuan, utamanya muslimah untuk tidak menampakkan perhiasan seperti gelang, anting, kalung dlln ${ }^{15}$. Pada riwayat lain, disebutkan perhiasan yang boleh tampak adalah perhiasan yang hanya boleh ditampakkan kepada suami, tidak pada lelaki lain yang bukan mahram.Hal ini jika dikaitkan dengan tarian viral para muslimah di aplikasi videomusik tik-tok maka ketika mereka menunjukkan lenggok tubuhnya adalah hal yang sama ketika mereka menunjukkan perhiasan mereka dihadapan lelaki lain, selain mahramnya. Perhiasan yang sifatnya fisik saja dilarang karena dapat mempercantik atau memperindah tubuh mereka, terlebih lagi itu adalah tubuh mereka.

Dalam tafsir muyassar surat An-Nur ayat 31 di jelaskan bahwa janganlah menunjukkan perhiasan kepada lelaki lain, tetapi berusahalah untuk menyembunyikannya pada pakaian luar yang biasanya dipakai, karena yang demikian itu agar mereka terhindar dari fitnah ${ }^{16}$.Menunjukkan bahwa tarian viral tersebut kaitannya dengan apa yang tidak biasa mereka tunjukkan kepada oranglain

\footnotetext{
${ }^{14}$ Munawwir, A. W. (1997). Kamus Al-Munawwir. Surabaya: Pustaka Progressif.

${ }^{15}$ Syaikh, A. B. M. A. Tafsir Ibnu Katsir Jilid 2. (2008).h.289

${ }^{16}$ Nukhbah Min Ulama. Tafsir Al-Muyassar. (2012). h.353.
} 
selain mahram/ suami mereka. Tidak selayaknya sebuah tarian yang menunjukkan kemolekan tubuh dipamerkan kepada lelaki lain yang bukan mahramnya.

Fenomena yang terjadi saat ini, eksistensialisme seorang perempuan bukan ditunjukkan dengan "perhiasan" yang berbentuk fisik seperti emas,perak,dlln. Akan tetapi, hiasannya adalah muslimah itu sendiri, menurut Musyfikah ilyas jika "perhiasan" tersebut disamakan dengan muslimah, maka keduanya adalah dua hal yang memiliki persamaan sama-sama indah dipandang, namun jika subjeknya adalah wanita maka orientasi hal tersebut tertuju bagi lelaki, karena sejatinya lelaki suka memandang kepada hal yang indah ${ }^{17}$.Hal tersebut jika dikaitkan dengan tampilan tarian muslimah di aplikasi video-musik tik-tok maka terdapat kesinambungan antar keduanya, yakni seorang perempuan muslimah yang menunjukkan dirinya beserta tarian yang meunjukkan lekuk tubuhnya hingga berakibat pandangan para lelaki yang tertuju padanya. Walaupun tubuh seorang perempuan muslimah sudah tertutup secara sempurna oleh hijab dan baju, akan tetapi apabila tubuhnya bergerak seakan melenggok-lenggok maka itu termasuk hal-hal yang sifatnya hampir sama dengan memamerkan aurat kepada lelaki yang bukan mahram.

Al-Qur'an melarang wanita untuk menampakkan dirinya dan bertingkah-laku seperti orang-orang Jahiliyyah sangatlah memuliakan wanita.Wanita diberikan sesuai dengan hak-hak dan kewajibannya,tak lebih dan tak kurang. Al-Qur'an menempatkan wanita dengan segala kehormatannya.Kehormatan yang ditunjukan kepada wanita salahsatunya berupa penjagaan kepada mereka. Sebagaimana disebutkan dalam surat Al-Ahzab ayat 33 Allah subhanahuwata'ala berfirman " Dan hendaklah kamu tetap di rumah-rumahmu dan janganlah kamu berhias dan bertingkah-laku seperti orang-orang Jahiliyyah yang dahulu".

Menurut tafsir Ibnu Katsir penetapan bagi para wanita untuk tetap dirumah yakni perintah kepada mereka untuk tidak keluar rumah kecuali ada kebutuhan/hajat yang memerlukan mereka untuk keluar rumah ${ }^{18}$, bahkan dalam suatu riwayat hadits nabi memerintahkan wanita untuk mengerjakan sholat dirumah mereka masingmasing, hal ini ditetapkan untuk menjaga diri mereka dari berbagai fitnah di luar rumah. Dilihat dari fenomena tarian viral para muslimah di aplikasi tik-tok menunjukkan ketidaksesuaian terhadap perintah ayat Al-Qur'an diatas. Pada zaman teknologi ini, semua orang tidak perlu bertemu secara nyata untuk saling berkomunikasi baik kepada sesama maupun lawan jenis, karena pada dasarnya fungsi teknologi komunikasi adalah untuk menyambungkan orang dari berbagai tempat, untuk mengurangi jarak yang memisahkan individu, negara dan waktu hal tersebut diungkapkan oleh McQuail ${ }^{19}$, sehingga semua orang bisa bertemu dan bersapa secara virtual.

Oleh karenanya, unggahan video-musik yang berisi tarian para muslimah di aplikasi tik-tok merupakan salah satu upaya "tunjuk diri" yang dilakukan para muslimah untuk mendapatkan perhatian dari semua orang, padahal dalam Al-Qur'an Allah melarang muslimah untuk keluar dari rumah tanpa kepentingan terlebih

\footnotetext{
${ }^{17}$ Ilyas, M. Memaknai Fashion Dalam Hukum Islam. Al Daulah: Jurnal Hukum Pidana Dan Ketatanegaraan, 5(1), 133-143.(2013).h.136

${ }^{18}$ Syaikh, A. B. M. A. Tafsir Ibnu Katsir Jilid 2. (2008).h.281

${ }^{19}$ Mcquail, D. Teori Komunikasi Massa. Jakarta : Penerbit Salemba Humanika. (2011).
} 
memamerkan kemolekan tubuhnya pada aplikasi jejaring video-musik tik-tok, dimana semua orang bisa mengaksesnya. Sebagai muslimah yang cerdas, selayaknya kita bisa menganalisis kaitan antara larangan yang telah Allah beri terhadap fenomena yang sedang terjadi,dilarangnya wanita untuk keluar dari rumah tanpa adanya hajat sama halnya dengan dilarangnya wanita untuk mengunggah foto maupun video yang tidak bermanfaat pada sosial-media, terlebih mengunggah video yang berisi tarian dimana hal tersebut menunjukkan kemolekan tubuhnya.

Larangan tentang berhias dan bertingkah laku layaknya orang Jahiliyyah dalam tafsir Ibnu Katsir dimaknai sebagai tindakan mereka yang bersikap lenggaklenggok, manja dan banyak bertingkah.Hal ini dapat disamakan dengan tarian para muslimah di aplikasi tik-tok yang menunjukkan kemolekan tubuh pada diri mereka. Sedang definisi berhias yang berlebihan adalah bagi mereka yang menggunakan hijab namun tidak diikat sehingga tak menutupi perhiasan yang dikenakannya seperti anting,kalung,dsb. Jika dikaitkan dengan fenomena saat ini banyak muslimah yang mengunggah video mereka di aplikasi tik-tok dengan menggunakan hijab yang tak seluruhnya menutup dada, bahkan tak jarang dari mereka menunjukkan sedikit rambutnya ataupun perhiasan seperti anting.

Al-Qur'an menyebutkan bahwa fungsi pakaian adalah penutup aurat.

Pakaian yang digunakan oleh tiap orang dalam kesehariannya berfungsi untuk menutupi bebrapa bagian tubuh yang seharusnya tak tampak. Dalam islam sendiri, aurat bagi laki-laki dan wanita sudah da ketentuannya. Berdasarkan perintah Allah untuk wanita agar menutupi seluruh tubuhnya kecuali wajah dan telapak tangan dihadapan lelaki non-mahram, Allah juga memerintahkan kepada lelaki untuk menutupi anggota tubuh bagian pusar hingga lutut ${ }^{20}$. Kedua aturan tersebut sudah diatur sebaikmungkin oleh sang pencipta untuk manusia seluruh alam.

Dalam firman Allah surat Al-Ahzab ayat 59 bahwasannya

"Hai Nabi katakanlah kepada isteri-isterimu, anak-anak perempuanmu dan isteri-isteri orang Mukmin: Hendaklah mereka mengulurkan jilbab ke seluruh tubuh mereka. Yang demikian itu supaya mereka lebih mudah dikenal, karena itu mereka tidak diganggu."

Dalam tafsir Ibnu Katsir disebutkan bahwa perintah kepada para muslimah untuk mengulurkan jilbab adalah agar dapat membedakan mereka dengan wanita jahiliyyah, tujuannya agar mereka tak mudah diganggu oleh orang-orang fasik ${ }^{21}$. Apabila kita samakan dengan fenomena pada saat ini, maka para muslimah yang gemar memamerkan tarian viral mereka di tik-tok adalah mereka yang sengaja menampakkan aurat dimana hal tersebut dapat menyebabkan fitnah/gangguan bagi wanita itu sendiri. Bahkan apabila pandangan seorang yang sedang takjub/kagum kepada tampilan foto/video seseorang maka hal itu bisa berdampak kepada penyakit ain dimana para penderitanya memiliki wajah yang agak kehitaman, hal tersebut berdasarkan hadits nabi yang diriwayatkan oleh bukhari muslim.

Menurut Tafsir Muyassar makna firman Allah dalam surat Al-Ahzab ayat 59

${ }^{20}$ Mardiah, R. Sistem Pergaulan Pria Dan Wanita Menurut Perspektif Alquran. Jurnal Penelitian Medan Agama, 10(2). (2019).h.249.

21 Syaikh, A. B. M. A. Tafsir Ibnu Katsir Jilid 2. (2008).h.383 
tersebut adalah perintah bagi para muslimah untuk menutupi wajah,dada dan kepala mereka dengan jubah/kain ${ }^{22}$. Agar terhindar dari hal-hal yang tidak diinginkan seperti celaan. Hal ini juga berakibat pada para muslimah yang gemar mengunggah video tarian pada apliaksi video-musik tik-tok. Setiap orang memiliki persepsi yang berbeda-beda atas tiap pendapat kita terlebih terhadap unggahan diri kita di sosial media, hendaknya kita lebih bijaksana dalam penggunaannya.

\section{KESIMPULAN}

Perkembangan teknologi membuat tiap orang mudah dalam mengakses apapun, salahsatunya aplikasi yang sedang hangat-hangtanya dibicarakan yakni aplikasi video-musik Tik-tok. Pengguna dari aplikasi ini terdiri dari banyak kalangan, salah satu yang mendominasi adalah para muslimah. Aplikasi tersebut memberikan banyak daya tarik bagi penggunanya, salahsatunya adalah konten tarian viral yang banyak diunggah oleh para influencer tik-tok, muslimah pun ikut menyemarakkan konten tersebut.Berdasarkan analisis banyak faktor penyebab para msulimah melakukan tarian tersebut yakni eksistensialisme yang ingin ditonjolkan oleh para muslimah, faktor gaya hidup yang membuat muslimah mudah mengikuti hal yang sedang viral, faktor lemahnya pengetahuan agama, dlln. Sedangkan dampak yang diterima para Muslimah yakni aurat mereka menjadi terbuka, mudah dilihat oleh lelaki non-mahram, memicu muslimah lain untuk mengikutinya dan dapat menyebabkan fitnah bagi muslimah itu sendiri. Pandangan Al-Qur'an dalam menyikapi fenomena konten tarian viral para muslimah di Aplikasi video-musik tiktok yakni terdapat dalam Surat An-Nur ayat 31 tentang larangan menampakkan aurat dihadapan non-mahram yang disamakn dengan menampakkan lenggokan tubuh muslimah pada konten tarian tersebut. Surat Al-Ahzab ayat 33 tentang larangan bagi muslimah untuk menampakkan dirinya di hdapan lelaki non-mahram, disamakan dengan eksistensialisme para muslimah pada konten tarial viral di aplikasi videomusik tik tok. Surat Al-Ahzab ayat 59 tentang fungsi pakaian untuk menutup aurat sebagaimana pada fenomena tersebut yakni fungsi pakaian menjadi disalahgunakan apabila para Muslimah tetap memamerkan kemolekan tubuhnya.Semoga Allah senantiasa menjaga kita dari perbuatan yang bermudharat.

\section{DAFTAR PUSTAKA}

Afanda, A. A. (2019). Kasus Penyebaran Hoaks Di Indonesia Dalam Sudut Pandang Filsafat Manusia.

Arrofi,Abdulhakim.(2019). Memahami Pengalaman Komunikasi Orangtua-Anak Ketika Menyaksikan Tayangan Anak-anak di Media Sosial Tik Tok . Jurnal Interaksi Online 7(3):203-208.

Amelia.R, dkk.(2021). Pesan Dakwah Husain Basyaiban dalam Konten Tik Tok.(Doctoral Dissertasion: UIN Sulthan Thaha Saifuddin Jambi).

${ }^{22}$ Nukhbah Min Ulama. Tafsir Al-Muyassar. (2012). h.426. 
Cahyani, Dini Dwi.(2021). Dampak Penggunaan Aplikasi Tik Tok dalam Interaksi Sosial (Study Kasus di SMA Negeri 11 Teluk Belitung Timur Bandar Lampung). (Doctoral Dissertasion : UIN Raden Intan Lampung).

Damayanti, T., \& Gemiharto, I. (2019). Kajian Dampak Negatif Aplikasi Berbagi Video Bagi Anak-Anak Di Bawah Umur Di Indonesia. Communication, 10(1), $1-15$.

Indirawati, E. (2006). Hubungan Antara Kematangan Beragama Dengan Kecenderungan Strategi Coping. Jurnal Psikologi, 3(2), 69-92.

Ilyas, M. (2016). Memaknai Fashion Dalam Hukum Islam. Al Daulah: Jurnal Hukum Pidana Dan Ketatanegaraan, 5(1), 133-143.

Rahmawati, S. (2018). Fenomena Pengguna Aplikasi Tik Tok Dikalangan Mahasiswa Universitas Pasundan Bandung (Doctoral Dissertation, PERPUSTAKAAN).

Tambunan, S. F. (2016). Kebebasan Individu Manusia Abad Dua Puluh: Filsafat Eksistensialisme Sartre. Jurnal Masyarakat Dan Budaya, 18(2), 59-76.

Sugiyono (2011). Metodologi Penelitian.

Tana, S. O., \& Bessie, J. L. (2020). Pengaruh Gaya Hidup Dan Kualitas Layanan Terhadap Keputusan Pembelian (Studi Pada Pelanggan X2 Family Resto And Karaoke Kupang). Journal Of Management: Small And Medium Enterprises (Smes), 13(3), 255-270.

Novianto, I. (2011). Perilaku Penggunaan Internet Di Kalangan Mahasiswa. Surabaya: Universitas Airlangga.

Prodi, P. T. I. K. (2020). Analisis Pertandingan Antara Facebook Ads Dengan Tiktok Ads Terbadap Perkembangan Bisnis Penjualan Online Di Era Digital. ICT Learning, 7(2).

Www.Medan.Tribunnews.Com Dilansir Oleh Taridan Turnip Pada 22 Oktober 2020 Dan Diakses Pada 3 Maret 2021.

Munawwir, A. W. (1997). Kamus Al-Munawwir. Surabaya: Pustaka Progressif.

Syaikh, A. B. M. A. (2008). Tafsir Ibnu Katsir Jilid 2.

Nukhbah Min Ulama (2012). Tafsir Al-Muyassar.

Mardiah, R. (2019). Sistem Pergaulan Pria Dan Wanita Menurut Perspektif Alquran. Jurnal Penelitian Medan Agama, 10(2).

Mcquail, D. (2011). Teori Komunikasi Massa. Jakarta : Penerbit Salmeba Humanika.

Www.Kominfo.go.id Dilansir oleh Ditjen PPI pada 09 November 2020 dan diakses Pada 02 Maret 2021. 